\title{
PROJEKT KONSTRUKCIJE STAKLENE STIJENE OVJEŠENE NA PREDNAPETIM KABLOVIMA
}

\author{
STRUCTURAL DESIGN OF CABLE NET WALL
}

\author{
Franko Milovan*, Nebojša Buljan**, Adriana Bjelanovićc
}

\begin{abstract}
Sažetak
Na primjeru projekta izvedene staklene stijene ovješene na prednapetim vertikalnim kablovima, u radu su kratko opisane njihove konstrukcijske značajke, a detaljnije razrađena načela proračuna. Uspoređeni su rezultati primjene dvaju pristupa u modeliranju: integralnog, koji uključuje i glavnu nosivu konstrukcije te interakciju u zonama oslonaca ostakljenja, te pojednostavnjenog, sa sekvencijalno modeliranim kablovima i simulacijom interakcije s glavnom konstrukcijom oprugama zamjenskih krutosti u točkama sidrenja kablova. Analizirane su prednosti, razlozi i posljedice primjene modela na ponašanje staklene stijene i cjelovite konstrukcije.
\end{abstract}

Ključne riječi: staklene stijene, prednapeti kablovi, modeliranje, nelinearna statička analiza, interakcija s glavnom nosivom konstrukcijom, ocjena ponašanja

\begin{abstract}
Structural design of cable net wall (CNW) with vertically pretensioned cables is used to give brief overview of basic structural performances of these façades and to elaborate the methodological specifies of their design. We compared results of the two applied approaches in modelling: the integral model with main load-bearing structure included, taking into account real interaction at zones of glazing supports; the simplified model with sequentially modelled cable, and springs of adequate stiffness, placed at points of cable anchorages, as simulation of interaction. Benefits, prerequisites for the application of these models and consequences they make on behaviour of glass façade and entire structural system were analysed.
\end{abstract}

Key words: cable net walls, modelling, nonlinear static analysis, interaction with load-bearing main structure, behaviour assessment

\footnotetext{
* Sveučilište u Rijeci, Građevinski fakultet, Radmile Matejčić 3, Rijeka

E-mail: \{franko.milovan,adriana.bjelanovic\}@gradri.uniri.hr

${ }^{* *}$ RI-ISA, d.o.o., Rijeka

E-mail: n.buljan@permasteelisagroup.com
} 


\section{Uvod}

Staklene stijene ovješene na prednapetim kablovima (CNW), konstrukcijski su izazovni sustavi jedinstvene estetike. Otkako je njemački konstruktor Jörg Schlaich projektirao prvi (Kempinski hotel, München, 1993.), zbog svoga atipičnog dizajna (prednapeti kablovi kao zamjena za krutu konstrukciju), transparentnosti i laganosti (povoljan udio vlastite težine u opterećenju), ovakvi sustavi afirmirali su se kao optimalni izbor za ostakljenja velikih površina i zahtjevne geometrije [1], [2] gdje je drugim tipovima ovješenih fasada teško postići takvu uravnoteženost ekonomskih i tehničkih svojstava. Potvrda tomu su mnogi izvedeni primjeri staklenih stijena aerodromskih terminala, hotelskih i poslovnih zgrada (Slika 1), izložbenih centara i reprezentativnih objekata drugih namjena [2], [3], [4], jer ovaj sustav, sa staklenom plohom kao sučeljem između eksterijera i unutrašnjosti zgrade, omogućava da fasada dostigne punu visinu velikih otvorenih prostora. Inovativnost CNW sustava temelji se na prilagodbama konfiguracije mreže i rasporeda kablova zbog utjecaja na prednapinjanje te optimizaciji oblika i materijala. Projektiranje staklenih stijena ovoga tipa zato je složen proces koji zahtijeva timski rad stručnjaka kompatibilnih kompetencija i vještina, razumijevanje funkcije i ponašanja konstrukcijskih materijala i dijelova stijene, njene interakcije $s$ glavnom nosivom konstrukcijom, kao i značaja preciznosti izvođenja za nosivost, stabilnost i funkcionalnost. Dodatno ga usložava i nedostatna popraćenost područja europskim normama i neujednačenost normizacije na svjetskoj razini. Rad koji čitate zasnovan je diplomskome radu [1] gdje je konkretni projektni zadatak bio i motivom za proučavanje šireg konteksta: detekcije ključnih problema čije rješavanje zahtijeva suradnju projektanata i izvođača, kao i smjernica istraživanja, relevantnih za razvoj normi, na temelju kratkog pregleda stanje područja. Prepoznat je interes istraživača u područjima ponašanja i proračunskih metoda staklenih fasada izloženih ekstremnim djelovanjima [5], utjecaja interakcije konstrukcijskih značajki (materijali, oblik, konfiguracija mreže i krutost staklenih ploča) na krutost i stabilnost stijene [4], [6] te dinamičkog odziva na pobudu vjetrom [7]. Za sve sustave staklenih fasada posebno su značajna i istraživanja u području otpornosti na djelovanje potresa i ponašanje u iznimnim okolnostima (eksplozija). Između navedenih tema, zainteresirale su nas problematika interakcije glavne nosive konstrukcije i staklene stijene ovješene na prednapetim kablovima, kao i učinci međusobne interakcije sastavnih konstrukcijskih dijelova ovoga sustava na ponašanje fasade te smo ih izdvojili kao okosnicu svoga rada. Konstrukcijske značajke ovih staklenih stijena [2], [3], [4], [8] opisane su u kontekstu provedbe proračuna i analize njihova ponašanja, na primjeru dostupnih podataka iz projekta staklene stijene izvedene na Međunarodnoj zračno j luci Mumbai [1], [9], [10], [11], a u središnjem se 
dijelu rada prezentiraju dva pristupa u modeliranju interakcije staklene stijene i glavne nosive konstrukcije, analiziraju se rezultati i opravdanosti njihove primjene te učinci koje imaju na ponašanje sustava.

\section{Konstrukcijske značajke sustava}
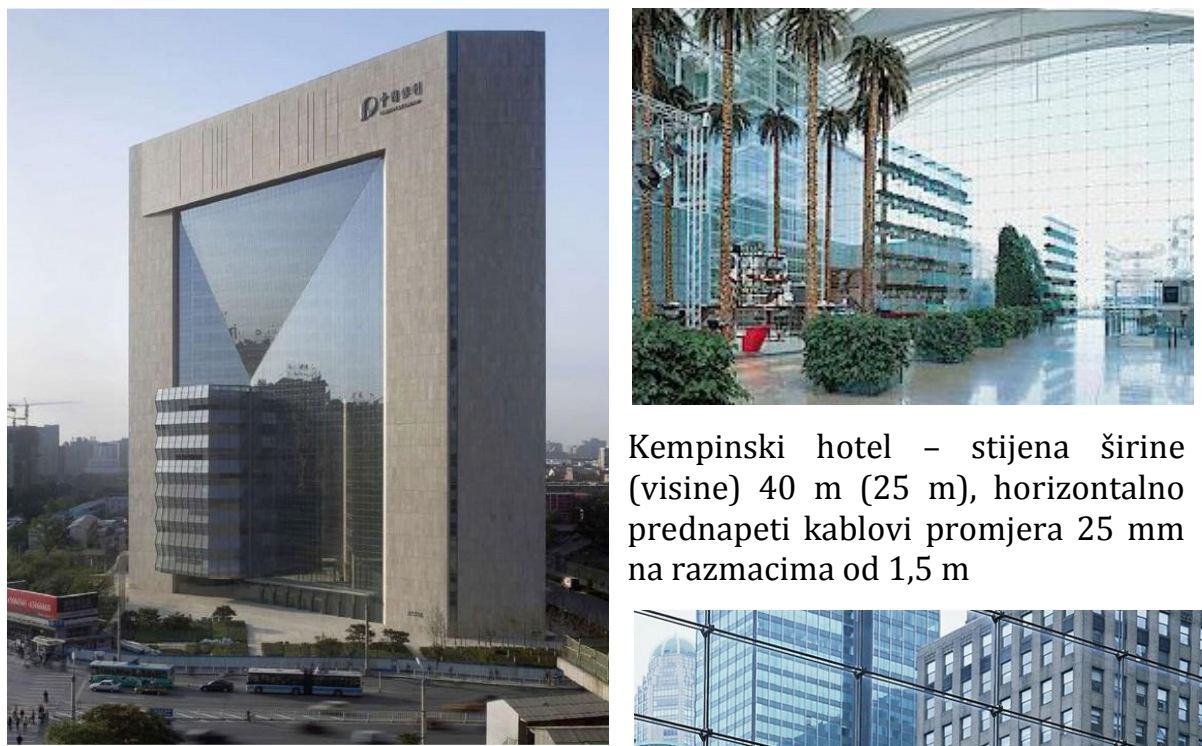

Kempinski hotel - stijena širine (visine) $40 \mathrm{~m}(25 \mathrm{~m})$, horizontalno prednapeti kablovi promjera $25 \mathrm{~mm}$ na razmacima od $1,5 \mathrm{~m}$

Peking New Poly Plaza - visine $90 \mathrm{~m}$ i širine $60 \mathrm{~m}, \mathrm{~s}$ kablovima promjera 34 $\mathrm{mm}$ (horizontalni) i $28 \mathrm{~mm}$ (vertikalni)

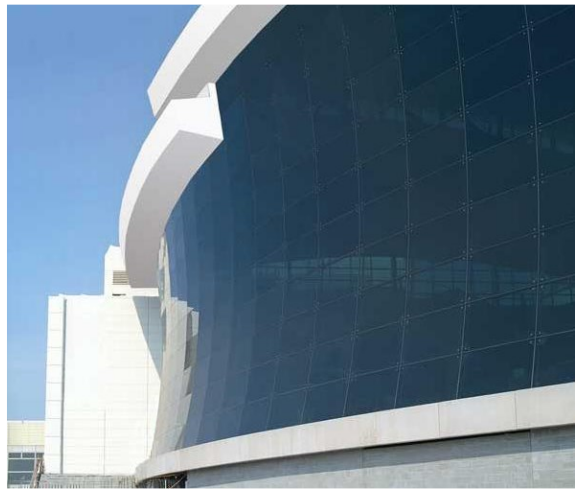

Seattle-Tacoma međunarodna zračna luka (Washington) - zakrivljena mreža

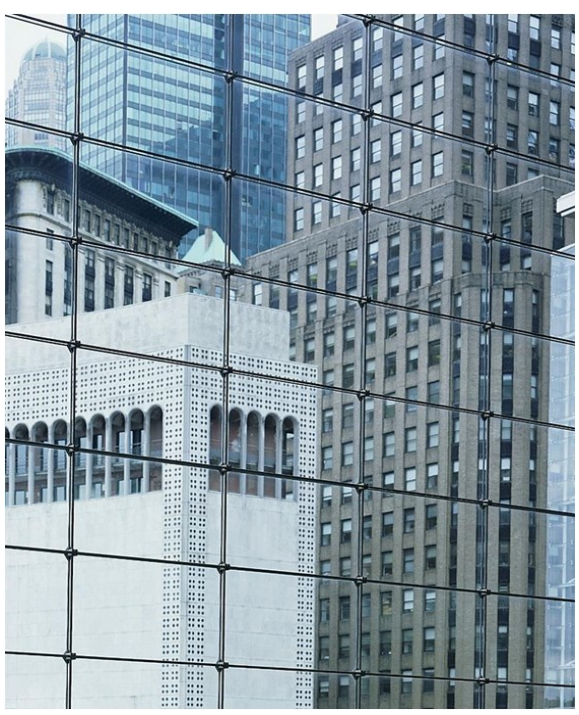

Time Warner Centar (Columbus Circle, New York) - visina 46 m i širina $25 \mathrm{~m}$, pravokutna mreža vert. i horiz. kablova promjera $28 \mathrm{~mm}$

Slika 1. Primjeri izvedenih sustava CNW [3], [4] 
Staklene stijene ovješene na prednapete kablove (CNW) podgrupa su sustava staklenih fasada (engl. structural glass façade, $S G F$ ) koje se vrstom potporne konstrukcije i sustavom brtvljenja razlikuju od ovješenih fasada. Staklene stijene nemaju okvir od aluminijskih ekstruzija, karakterističan za ovješene fasade, a sve tri glavne komponente (staklo, sustav ostakljenja i potporna konstrukcija) integrirane su jedinstven sustav, potpuno izložen, transparentan i minimalističkog izričaja. Osjetan je trend primjene vlačnih konstrukcijskih sustava, poput CNW [2], [3], [8] (Slika 1), s nosivim kablovima jednog smjera (vertikalni ili horizontalni) ili u dva ortogonalna (ravna ili zakrivljena mreža) [1]. Opterećenje na staklo prenosi sustav ostakljenja na potpornu, a odatle na glavnu nosivu konstrukciju (npr. stupove i grede). Mreža prednapetih čeličnih kablova je fleksibilna potpora ostakljenju, a zbog geometrijske nelinearnosti izložena izrazitim progibima.

Kolaps mreže može izazvati gubitak napetosti kabela ili nosivosti sidara, a oboje nepovoljno utječe na stabilnost stijene. Utjecaj krutosti stakla na krutost stijene također se ne smije zanemariti. Za stijene ravne plohe on je manji nego li je to slučaj sa zakrivljenim stijenama [4], [6], a za oba tipa plohe ima povoljan učinak na prigušenje vibracija od opterećenja vjetrom [4], [5], [7]. Prednapinjanje značajno smanjuje deformiranje dvosmjernih kablovskih mreža i stabilizira staklenu stijenu. Gravitacijska opterećenja (vlastita težina staklenih ploča) prihvaćaju se na mjestima povezivanja s vertikalnim kabelima i sidrenja u glavnu nosivu konstrukciju, a prirodna intencija izravnavanja svih kabela na duljini između oslonaca pruža otpor deformiranjima zbog vjetra i seizmičkih sila. Progibe kabela do graničnih vrijednosti od L/40 do L/50 reguliraju prilagodbe osnih krutosti i sila prednapinjanja kabela [1], [2]. Svrha ograničenja progiba (za najkraći raspon $L$ i 50-godišnji povratni period opterećenja vjetrom) jest zaštita cjelovitosti staklenih ploča i silikonskih brtvi između susjednih staklenih ploča te jamstvo funkcionalnosti stijene, a prevladava kriterij percepcija pomaka sa stajališta ugode korisnika. Značajan doprinos smanjenju deformiranja može biti i zakrivljenost stijene (npr. antiklastične plohe) jer kablovi, položeni u dva glavna smjera suprotnih zakrivljenosti, kreiraju krutu mrežu.

Poprečno opterećene stijene zakrivljene geometrije manje su deformabilne od ravnih ploha i zato jer je zakrivljenost kabela i prevencija nedeformiranog početnog stanja (najosjetljiviji dio nelinearnog odziva na ovo opterećenje). Svaki svaki smjer kablova antiklastične mreže prihvaća polovicu poprečnog opterećenja (umjesto da se pojedini smjer ortogonalnih ravnih mreža optimizira za prihvat ovoga opterećenja). U ovoj konfiguraciji, sidra na svakoj strani mreže moraju moći prihvatiti polovicu opterećenja cijele stijene vjetrom te treba zadovoljiti stroge rubne uvjeta na sve četiri strane. U usporedbi s ravninskima, sustavi s antiklastičnim mrežama mogu se projektirati za granične progibe od L/40 - L/50 sa značajno manjim 
silama prednapinjanja, a s punim učinkom prednapinjanja zadovoljavaju i ograničenja progiba od L/120 [2], [3], [4].

\section{Statički proračun staklene stijene Terminala 2}

\subsection{Projekt zračne luke Mumbai i staklene stijene Terminala 2}

Međunarodna zračna luka Chhatrapati Shivaji najveće je indijsko središte međunarodnog i domaćeg zračnog prometa. Zbog gospodarskog razvoja grada Mumbai i putničkog prometa, 2014. god. izrađen je projekt rekonstrukcije postojeće zračne luke Sahar s predviđenom gradnjom novog terminala (Terminal 2), a Arhitektonski je ured Skidmore, Owings \& Merrill LLP pronašao inspiraciju (Slika 2) u izgledu tradicijskih indijskih paviljona te je projekt uspješan spoj obilježja tradicije, kulture i novog tehnološkog uzleta države [1], [9], [10].

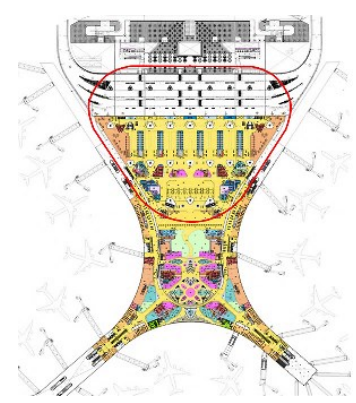

Tlocrt zračne luke

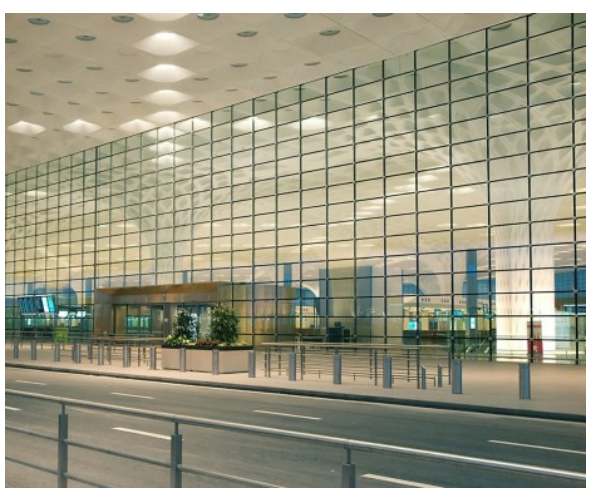

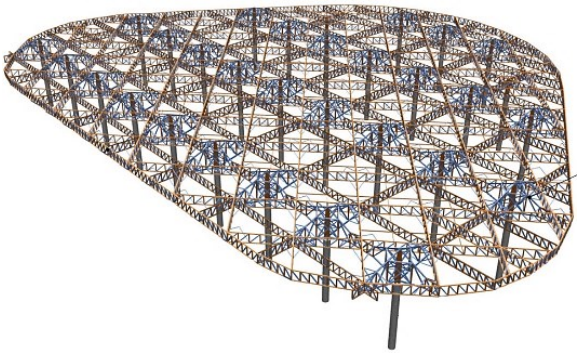

Roštiljna rešetkasta konstrukcija krova

Sjeverna staklena fasada Terminala 2

Pojednostavljena shema i statički sustav jednostrukog kabela razmaci oslonaca (uglovi staklenih ploča) iznose $1,0 \mathrm{~m}$

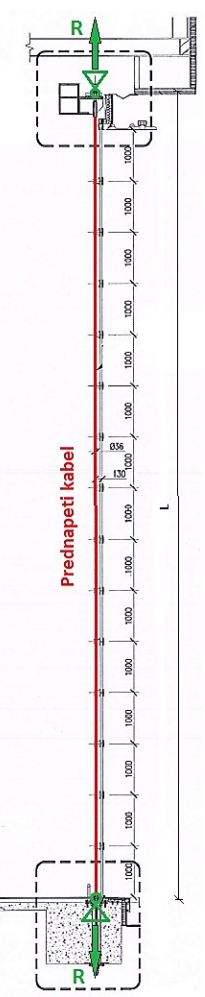

Slika 2. Lokacija i krovna konstrukcija Terminala 2, izgled i statički sustav sjeverne staklene fasade [1], [9], [10], [11] 
Dinamična forma krova i staklena fasada na 4. katu Terminala omogućavaju uvid u veličinu zgrade. Krovna konstrukcija (Slika 2) se oslanja na 30 masivnih stupova. Površinom od $70000 \mathrm{~m}^{2}$, najveća je na svijetu izvedena bez dilatacijskog spoja. Rasponi između stupova su od 34 $\mathrm{m}$ do $64 \mathrm{~m}$, a povećana visina rešetke iznad njih omogućila je izvedbu velikih konzola po obodu zgrade terminala [9], [10]. Staklena fasada zgrade Terminala 2 (Slika 2) ovješena je na prednapete vertikalne kablove. Duga 900 m, najduža je izvedena ovoga tipa dosad. Razmaci kablova najveće duljine 15,5 m iznose 1,7 m. Kablovi su izvedeni od nehrđajućeg čelika promjera 20 - $36 \mathrm{~mm}$ (korak je $4 \mathrm{~mm}$ ), a na krajevima se sidre u donji pojas čelične rešetke te armiranobetonsku gredu. Stakleni paneli dimenzija 1,0 x $1,7 \mathrm{~m} \mathrm{su}$ „kliještima“ pričvršćeni na kablove (Slika 2) [11].

\subsection{Statički sustav staklene fasade i opterećenja}

Statički sustavi staklenih fasada s kablovima (prednapinjanje nije uvijek nužno) dijele se u skupine onih koji prenose opterećenje na glavnu nosivu konstrukciju (Slika 3a, 3c i 3d) i samonosivih (Slika 3b i 3e). U staklenim fasadama ovješenima na prednapete kablove prevladava sustav (a) $s$ kablovima (dvostruki su iznimka) usidrenim na krajevima. Takva je konstrukcija fleksibilna, a opterećenja na glavnu konstrukciju prenose samo osne sile. Sustavi (b) i (e) su "zatvoreni", ne prenose opterećenje na glavnu konstrukciju, a uravnoteženje se odvija između vlačnih kablova i tlačne cijevi. U sustavima (c) i (d) opterećenje se prenosi na glavnu nosivu konstrukciju, a uravnoteženje se postiže sidrenjem kablova, slično sustavu (a) koji je primijenjen i za staklenu fasadu zračne luke Mumbai (Slika 2).

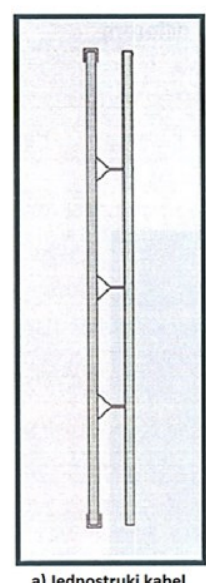

a) Jednostruki kabel
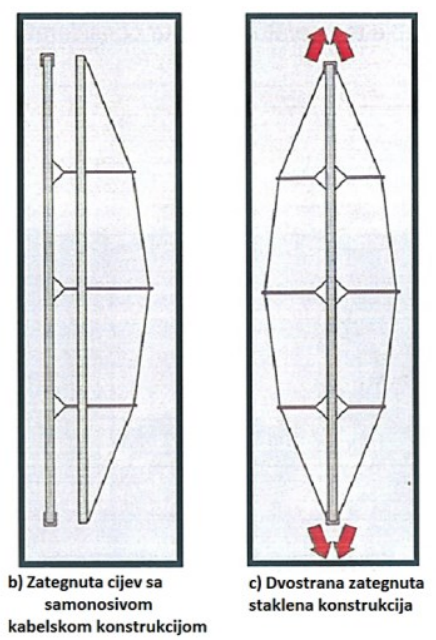

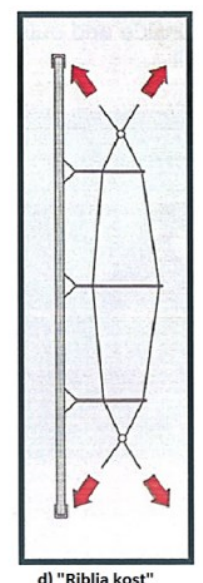

d) "Riblja kost"

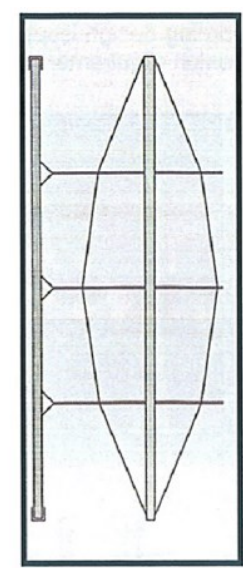

e) Lećasti profil

Slika 3. Statički sustavi staklenih fasada s kablovima [1], [3] 
Preostali kablovi fasade Terminala 2 razlikuju se duljinom, promjerom $\mathrm{i}$ silom prednapinjanja, a statički sustav odgovara pojednostavnjenoj shemi (Slika 2). Zglobni oslonci su nepomični, a takvo ponašanje omogućavaju rotacije krajeva kabela (deformirani zbog opterećenja). Rotaciju kablova većih promjera omogućavaju i sferno oblikovani umetci u osloncima.

Za staklene fasade ovog tipa posebno su važna opterećenja vjetrom (zbog velike površine i malene težine stijene), a sva druga (vlastita težina stakala, kablova i opreme te promjena temperature) neizostavno pripadaju setu ulaznih podataka statičkog proračuna. Dinamička svojstva i odziv na opterećenja od potresa i eksplozije nisu predmet ovog rada. Analiza opterećenja preuzeta je iz dokumentacije statičkog proračuna fasade (projekt Global Tech Design, Singapore, Pte Ltd) na temelju kojeg je provedena dodatna ekspertiza [11]. Više podataka o opterećenjima koji su ulazni podaci u analizi modela navedeno je u [1] .

\subsection{Modeli konačnih elemenata (KE) za nelinearni statički proračun}

Ponašanje većine inženjerskih konstrukcija je linearno, ali analiza neki problema zahtijevaju drugačiji pristup zbog nelinearnosti u području materijala, geometrije ili rubnih uvjeta. Geometrijska nelinearnost ne smije se zanemariti u proračunu i modeliranju staklenih fasada ovješenih na prednapete kablove jer promjene u geometriji značajno utječu na svojstva krutosti konstrukcije. Proračun prednapetih kablova zahtijeva pravilno i detaljno razmatranje oslonaca jer model mora uključivati realne krutosti konstrukcije na koju se kabel sidri, a računalni paket omogućiti primjenu kabelskih KE (engl. cable $F E$ ) s mogućim unosom sile prednapinjanja za aktivaciju osnih sila, kao zamjenu za simulaciju skraćenjem duljine zbog temperature. Za proračun staklene fasade razvijena su dva modela, različita tretmanom interakcije s glavnom nosivom konstrukcijom: prvi (integralni model, A) uključuje i glavnu nosivu konstrukciju, a u drugom (sekvencijalni model, B) se interakcija simulira nizom opruga zamjenskih krutosti.

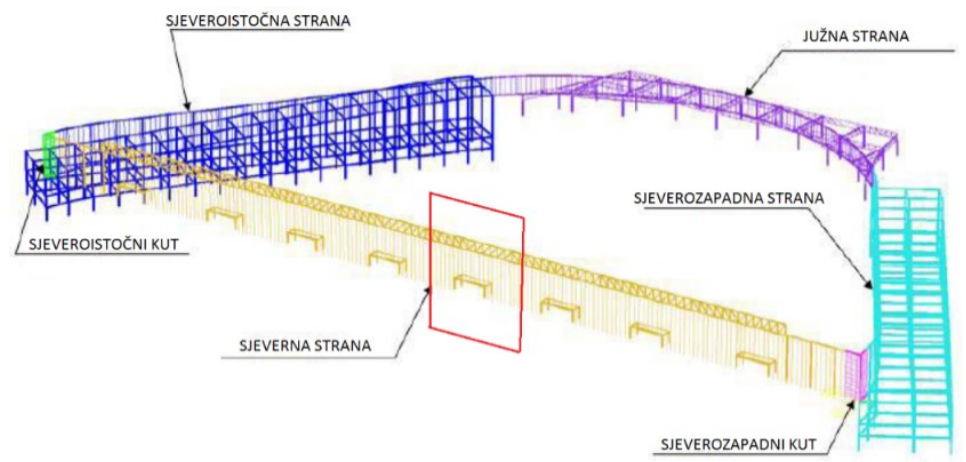

Slika 4. Karakteristični segment (crveni obrub) staklene fasade [1] 
Analize modela KE provedene su u programskom paketu Strand 7 (Straus), a razmatran je karakteristični segment staklene fasade unutar jednog polja krovne rešetke na sjevernoj fasadi Terminala 2 (Slike 4 i 5). U proračunu graničnih stanja [1], za oba modela (A i B), utjecaj promjene temperature u čvorovima oslonaca stakla i kablova modeliran je kao smanjenje za $15{ }^{\circ} \mathrm{C}$, odnosno kao povećanje od $30^{\circ} \mathrm{C}[1]$.
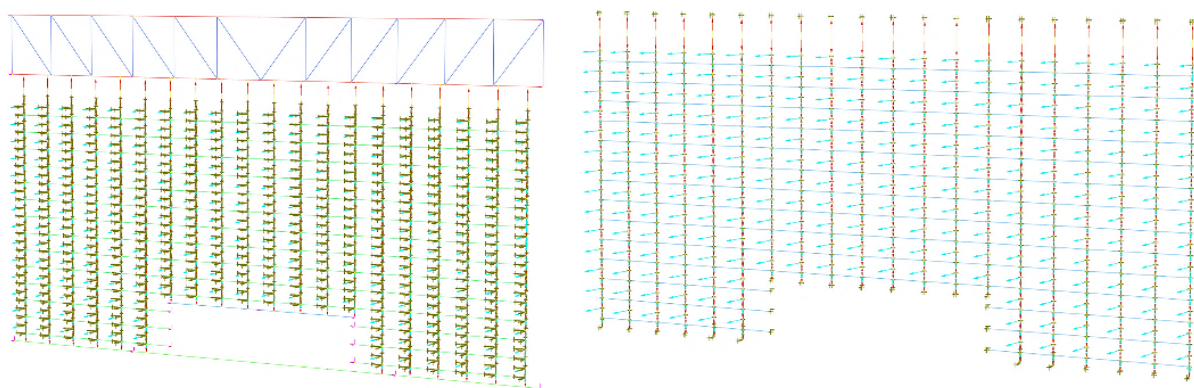

Slika 5. Analizirani modeli KE - model A (lijevo) i model B (desno)

\subsubsection{Model A - integralno modeliranje glavne nosive konstrukcije i kablova}

U Modelu A (Slika 5) kablovi su usidreni na rešetkastu čeličnu krovnu konstrukciju (gornji oslonac) te armiranobetonsku gredu i ulazni portal (donji oslonci). Elementi i dijelovi glavne nosive konstrukcije modelirani su s grednim KE (engl. beam FE) [1], a geometrija i izvedbena rješenja detalja preuzeti su iz dokumentacije projekta [9], [10], [11]. Kontinuirana čelična rešetkasta konstrukcija visine $3,5 \mathrm{~m}$ i raspona polja $34 \mathrm{~m}$, modelirana je od kvadratnih cijevi $300 \times 300 \times 40 \mathrm{~mm}$ (ispuna) i H profila 437 x $417 \mathrm{~mm} \mathrm{~s}$ hrptom i pojasnicama debljina 40 (60) $\mathrm{mm}$ (pojasevi rešetke). Rešetka se oslanja u krajnjim čvorovima gornjeg i donjeg pojasa radi simulacije kontinuiteta i prevencije translacijskih pomaka u tri okomita smjera. Pojednostavljenje omogućava velika krutost čvorova zbog roštiljnog djelovanja rešetkaste konstrukcije. Armiranobetonska greda je modelirana kao puni betonski element dimenzija 1000 x $1200 \mathrm{~mm}$ (zbog nepoznavanja vrste i količine ugrađene armature, zanemaren je doprinos armaturnog čelika krutosti), s osloncima na razmaku od $8,5 \mathrm{~m}$ (pozicije stupova). Oslonci se smatraju krutima, a translacijski pomaci su spriječeni u sva tri okomita smjera. Ulazni portal (donji oslonac za 8 kablova) modeliran je kao čelični okvir preko dva jednaka raspona, s gredom raspona $5,95 \mathrm{~m} \mathrm{od}$ cijevnih profila ( $400 \times 600 \times 30,0 \mathrm{~mm}$ ) i stupovima od I-profila (550 × 640 mm s hrptom i pojasnicama debljina $20 \mathrm{~mm}$ i $35 \mathrm{~mm}$ ) [1].

Prednapeti kablovi staklene fasade promjera su 28, 32 i $36 \mathrm{~mm}$. Sile prednapinjanja, pozicije kablova duljine kablova 15,9 m i 12,9 m (nad ulaznim portalom), te konstantni raster $(1,7 \mathrm{~m})$ preuzeti su iz projektne 
dokumentacije. Točke oslonaca stakla su mjesta unosa opterećenja od vjetra, promjena temperature te vlastite težine stakla i opreme u kabel. Pojednostavnjenja radi, ali s dostatnom razinom točnosti proračuna, svi kablovi i staklo, modelirani s rešetkastim KE (engl. truss FE), kao osno napregnuti elementi. Ostakljenje fasade je zbog znatnog doprinosa stakala (ploče dimenzija $1000 \times 1700 \times 40 \mathrm{~mm}$ ) krutosti konstrukcije, sastavni dio modela, a stakla su oslonjena u dvjema točkama spoja s kablovima [1], [11].

\subsubsection{Model B - pojednostavnjen sekvencijalnim modelom kablova i oslonaca}

Tablica 1. Krutosti točaka sidrenja kablova [1]

\begin{tabular}{|c|c|c|c|c|c|c|}
\hline \multicolumn{7}{|c|}{ KRUTOSTI OPRUGA OSLONACA KABLOVA U MODELU } \\
\hline \multicolumn{3}{|c|}{ VERTIKALNO (U RAVNINI) } & \multicolumn{3}{|c|}{ HORIZONTALNO (IZVAN RAVNINE) } & \multirow{3}{*}{$\overbrace{0}^{\circ}$} \\
\hline REŠETKA & GREDA & PORTAL & $\begin{array}{c}\text { REŠETK } \\
\text { A }\end{array}$ & GREDA & PORTAL & \\
\hline $\begin{array}{l}\text { krutost } k \\
{[\mathrm{~N} / \mathrm{mm}]}\end{array}$ & $\begin{array}{l}\text { krutost } k \\
{[\mathrm{~N} / \mathrm{mm}]}\end{array}$ & $\begin{array}{c}\text { krutost } k \\
{[\mathrm{~N} / \mathrm{mm}]}\end{array}$ & $\begin{array}{c}\text { krutost } k \\
{[\mathrm{~N} / \mathrm{mm}]}\end{array}$ & $\begin{array}{c}\text { krutost } k \\
{[\mathrm{~N} / \mathrm{mm}]}\end{array}$ & $\begin{array}{c}\text { krutost } k \\
{[\mathrm{~N} / \mathrm{mm}]}\end{array}$ & \\
\hline 725589,36 & 3553799,19 & & 78890,48 & 2467917,08 & & 1 \\
\hline 770701,03 & 706978,59 & & 10055,33 & 490956,58 & & 2 \\
\hline 313775,69 & 552391,58 & & 4154,36 & 383606,21 & & 3 \\
\hline 342564,30 & 892347,23 & & 2423,49 & 619686,19 & & 4 \\
\hline 223558,11 & 5765317,01 & & 1678,79 & 4003699,42 & & 5 \\
\hline 190260,56 & 6041018,52 & & 1292,12 & 4195141,19 & & 6 \\
\hline 188720,55 & & $\sim$ & 1070,07 & & $\sim$ & 7 \\
\hline 143754,58 & & 238199,02 & 937,81 & & 123665,19 & 8 \\
\hline 159881,05 & & 189831,49 & 861,24 & & 98554,21 & 9 \\
\hline 142426,00 & & 922773,12 & 825,76 & & 479071,75 & 10 \\
\hline 142426,00 & & 922773,12 & 825,76 & & 479071,75 & 11 \\
\hline 159881,05 & & 189831,49 & 861,24 & & 98561,01 & 12 \\
\hline 143754,58 & & 238199,02 & 937,81 & & 123665,19 & 13 \\
\hline 188720,55 & & $\sim$ & 1070,07 & & $\sim$ & 14 \\
\hline 190260,56 & 6041018,52 & & 1292,12 & 4195141,19 & & 15 \\
\hline 223558,11 & 5765317,01 & & 1678,96 & 4003699,42 & & 16 \\
\hline 342564,30 & 892347,23 & & 2423,49 & 619686,19 & & 17 \\
\hline 313775,69 & 552391,58 & & 4154,36 & 383606,21 & & 18 \\
\hline 770701,03 & 706978,59 & & 10055,33 & 490956,58 & & 19 \\
\hline 725589,36 & 3553799,19 & & 78890,48 & 2467917,08 & & 20 \\
\hline
\end{tabular}


Model B (Slika 5) se samo prema vrsti analiziranih konstrukcijski elemenata razlikuje od prethodnog: posredno sidrenje kablova u gornju i donju nosivu konstrukciju (izostavljene su iz modela) simulira niz opruga zamjenskih krutosti u tri međusobno okomita smjera. Konstrukcijski doprinos glavne nosive konstrukcije uzima se u obzir odgovarajućim krutostima zamjenskih opruga u točkama sidrenja kablova (Tablica 1). Horizontalna krutost oslonaca $\mathrm{u}$ ravnini fasade pretpostavljena je beskonačno velikom [1].

\subsection{Modeli interakcije staklene stijene i glavne nosive konstrukcije}

Osobitosti u interakciji staklene stijene i glavne nosive konstrukcije izuzetno su bitne u ocjeni i razumijevanju ponašanja ovih sustava. Pravilno tretiranje oslonaca za prijenos sile prednapinjanja važno je za modeliranje podložnih pločica, zavara i vijaka jer nepreciznosti definiranja opterećenja smanjuju sigurnost spoja i uzrokom su zaostalih deformacija. Deformiranje „mekanog“ oslonca (iako pričvršćenog na krutu konstrukciju) pritezanjem i eksploatacijom kablova može prouzročiti znatniji pad sile prednapinjanja i povećanje progiba kablova. Također, za projektiranje robusne i sigurne staklene stijene važno je pouzdano predvidjeti vrste i vjerojatnosti pojave posrednih opterećenja na glavnu konstrukciju poput skupljanja i puzanja, slijeganja temelja, prometnih opterećenja, te izvanrednih (eksplozija) i seizmičkih [1], [2], [4], [5]. To upućuje na složenost mehanizama interakcija i važnost uravnoteženja u izboru materijala, statičkog sustava i priključaka.

Nadalje, u analizi ponašanja modela ne smije se zanemariti niti međusobna interakcija dijelova fasade (kablovi i staklo). Važna je zbog utjecaja ostakljenja na krutost stijene te raspodjele sila važnih za provjere naprezanja u staklu i konstrukcijskom silikonu. Interakcija kablova i stakla važna je za razmatranje načina deformiranja i diferencijalnog progiba $u$ točkama oslanjanja stakla jer može izazvati vitoperenje staklenih ploča i nepovoljna naprezanja na rubovima. Također, kad se instalacija kablova odvija u uvjetima temperatura nižih od onih koje se predviđa u projektu, kablove treba prednapeti većom silom od projektirane, kao kompenzaciju naknadnih opuštanja zbog temperaturne razlike. Na povećane sile prednapinjanja treba provjeriti oslonce i pojavu povećanih progiba glavne nosive konstrukcije koji mogu izazvati pad sile u kablovima [1], [2], [4].

Naknadno pritezanje kablova, ako je potrebno (npr. onda kad se očekuju znatniji učinci dugotrajnih deformacija), treba predvidjeti projektom i propisati jasnu proceduru, a tomu prilagoditi tehnologiju i raspoloživ prostor. U pravilu se naknadno pritezanje može izbjeći i ugradnjom opruga $\mathrm{u}$ ležajeve kabela (npr. u jednostavnim sustavima $\mathrm{s}$ maticom i kontrapločom, hidraulikom se istegne kabel kontroliranom silom i pritegne matica). 


\subsubsection{Usporedba rezultata proračunskih modela A i $B$}

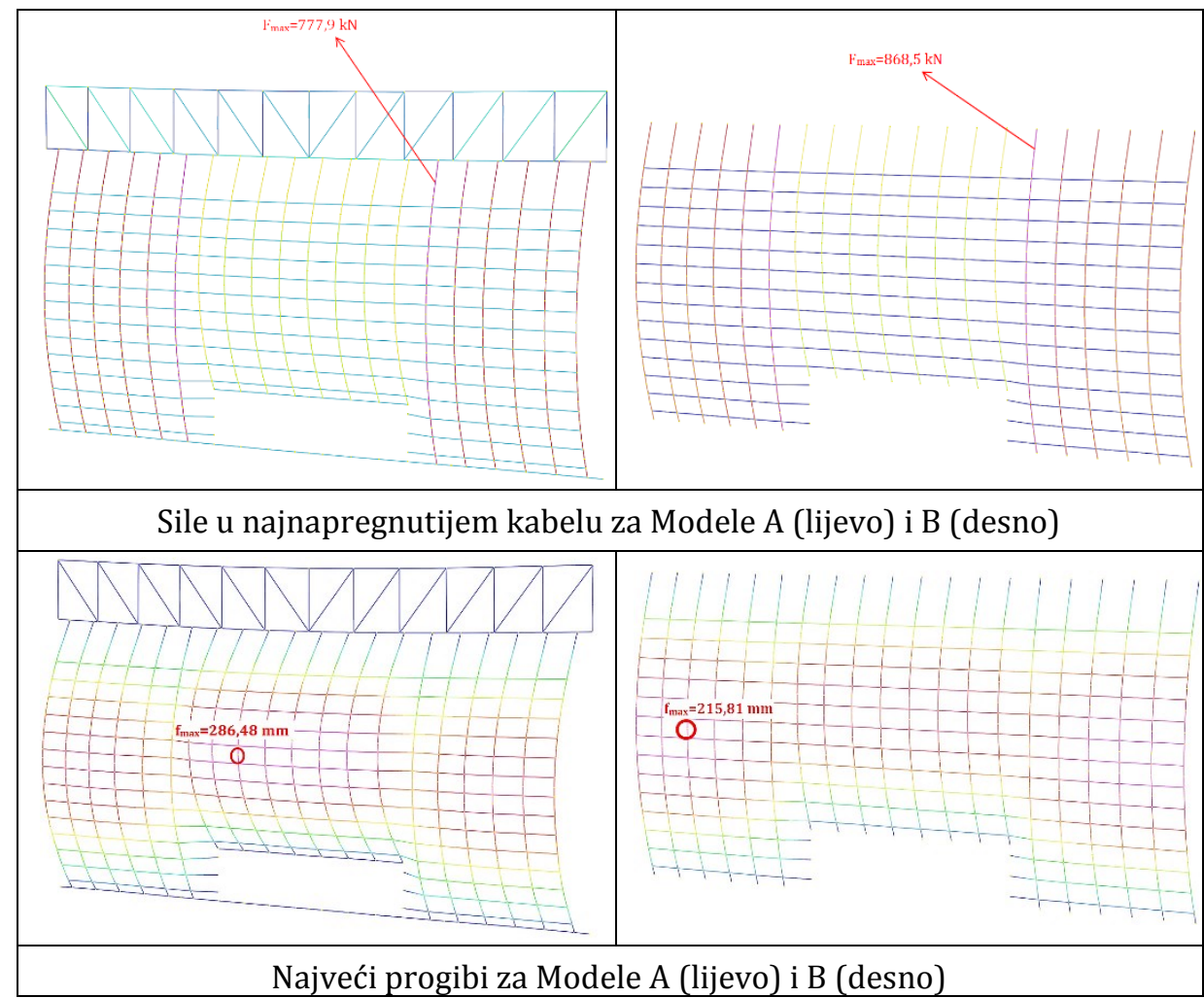

Slika 6. Rezultati provjera graničnih stanja nosivosti i uporabljivosti [1]

Ilustracija razlika koje proizlaze iz primjene Modela A i Modela B su sile u kablovima (za granično stanje nosivosti) i najveći progibi, izmjereni u čvorovima staklene fasade (za granično stanje uporabljivosti) prikazane na Slici 6. Na njima je vidljivo da izbor modela ne utječe na položaj najnapregnutijih kablova, ali mijenja položaj točke s najvećim progibom [1]. Rezultat primjene Modela B je za 10,4\% veća sila u kabelu i 24,7\% manji progib u odnosu na vrijednosti dobivene Modelom A.

\subsubsection{Utjecaj pomaka glavne konstrukcije na progib i sile u kablovima}

Tijekom projektiranja staklene fasade može biti teško procijeniti pomake glavne konstrukcije i odrediti njihov utjecaj na staklenu stijenu. 


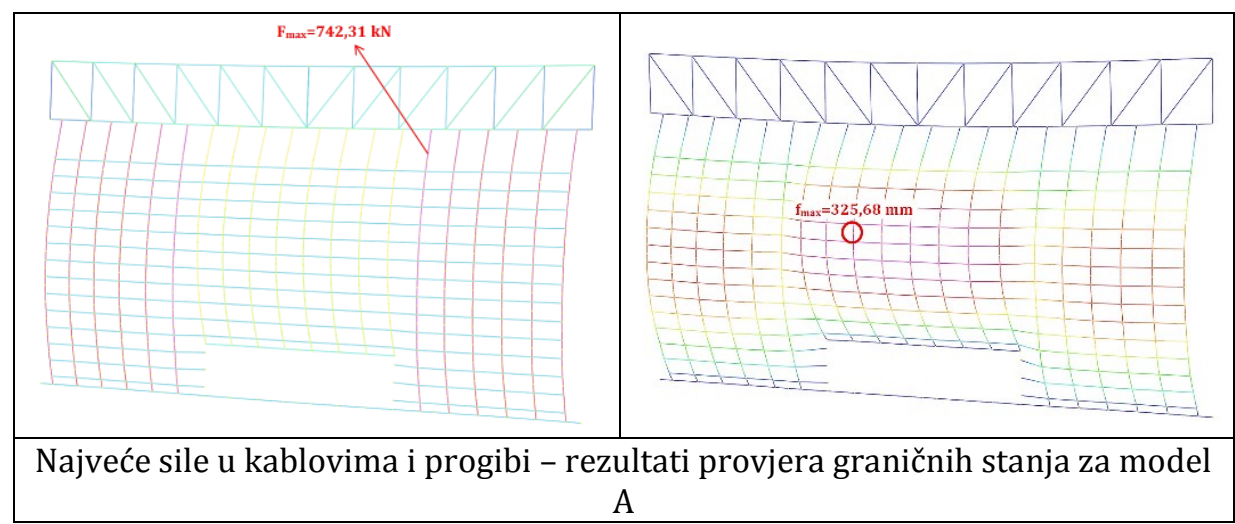

Slika 7. Rezultata provjera za prirast vertikalnog pomaka rešetkaste glavne konstrukcije od $10 \mathrm{~mm}$ [1]

Zbog osvješćivanja potrebe provedbe detaljne analize opterećenja $u$ proračunu glavne konstrukcije te suradnje s projektantima svih dijelova građevine bitnih za ponašanje fasade, na Slici 7 zato je prikazan utjecaj proizvoljnog prirasta pomaka glavne konstrukcije na povećanja progiba i pad sile prednapinjanja u kablovima. Prirast vertikalnog pomaka u sredini raspona glavne konstrukcije od $10 \mathrm{~mm}$ obuhvaća učinke izgledne pojave tijekom uporabnog vijeka i utjecaj rubnih uvjeta (onemogućeni vertikalni pomaci) na krajevima raspona rešetkaste glavne konstrukcije. Analiza je provedena za Model A, a vertikalni pomak ostvaren unosom opterećenja u čvorove gornjeg pojasa rešetke. $U$ usporedbi s rezultatima prikazanima na Slici 6, vidljiv je porast početnog progiba za $39,2 \mathrm{~mm} \mathrm{(13,7 \% ),} \mathrm{dok} \mathrm{sila} \mathrm{u}$ kabelu pada za 35,59 $\mathrm{kN}(4,58 \%)$ zbog međusobnog približavanja točaka oslanjanja kablova [1]. Zato se može zaključiti da je utjecaj pomaka glavne konstrukcije na staklenu fasadu značajan poput promjene temperature te veličinu prirasta pomaka treba dogovoriti s klijentom i/ili konzultantom.

\subsection{Modeliranje i proračun prednapetih kablova}

Provjere graničnih stanja provedene su za kabel s najvećom silom, dobivenom iz analize Modela A (Slika 6), a izuzetno su zanemareni učinci prirasta pomaka glavne nosive konstrukcije (Slika 7). Korištene oznake kablova preuzete su iz projektne dokumentacije [1], [11]. Provjere su provedene za karakteristični kabel F4NW15, a oznake i početne sile prednapinjanja (prema projektnoj dokumentaciji) prikazane su na Slici 8. Prema katalogu proizvođača Brugg, lomna sila za kabel F4NW15 promjera $36 \mathrm{~mm}$ iznosi $962 \mathrm{kN}$ te provjera zadovoljava za silu od 777,9 kN [1]. 


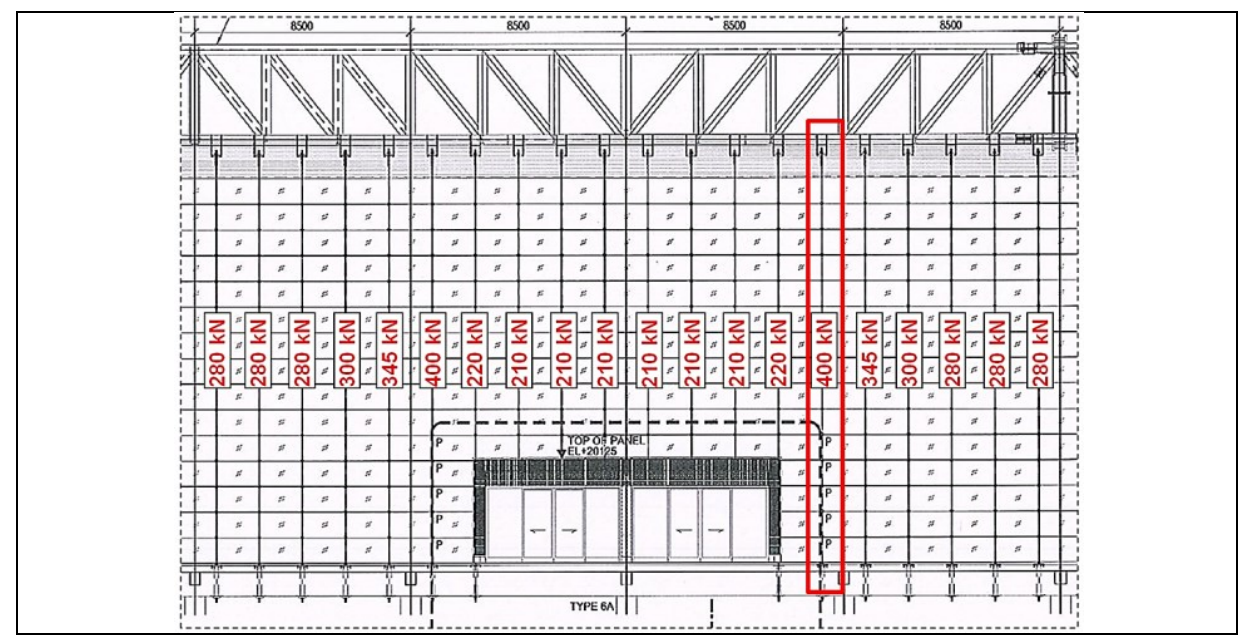

Slika 8. Dispozicija staklene stijene i položaj kabela F4NW15 [1]

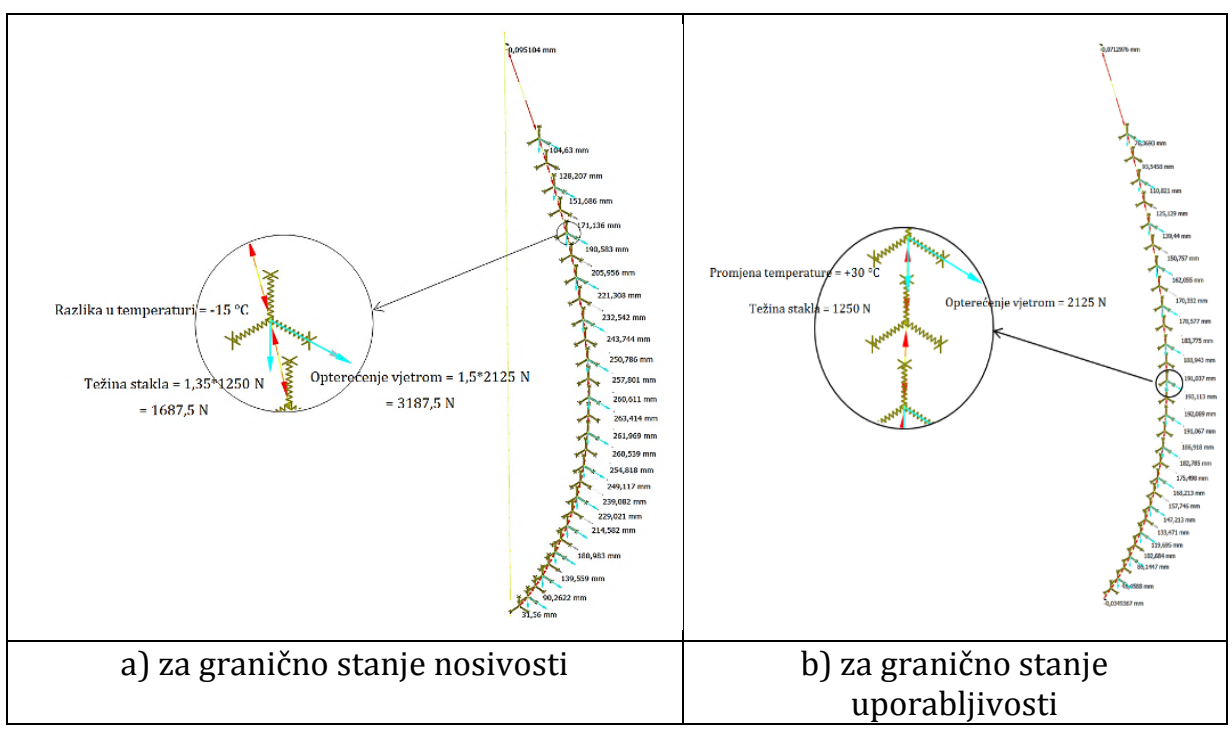

Slika 9. Detalji kabela F4NW15 za proračun graničnih stanja [1]

Sila je rezultat analize Modela A (Slika 6), za vertikalno opterećenje (Slika 8) od 417,5 kN (početna sila prednapinjanja od $400 \mathrm{kN}$ uvećana za težinu 15 staklenih ploča) te opterećenjima vjetra u čvorovima staklenih ploča i temperature (Slika 9). Granični progib kabela F4NW15 duljine $L=$ $15900 \mathrm{~mm}$ (kriterij L/50) iznosi $318 \mathrm{~mm}$ te zadovoljava provjeru za proračunski progib 193,11 mm (Slika 9). Progibi kabela duljine 12,9 m iznad portala prelaze graničnu vrijednosti od 258 mm (Slike 6 i 7). 


\subsection{Modeliranje i proračun stakla}

Provjera za granično stanje nosivosti provedena je za karakteristično staklo u stijenama ovoga tipa, a za granično stanje uporabljivosti za staklo smješteno između kabela s najvećim relativnim progibom (Slika 10). U provjeri nosivosti razmatrana je i pojava vitoperenja stakla dimenzija 1,0 x $1,7 \mathrm{~m}$ uslijed značajne razlike relativnih pomaka uglova (točke oslanjanja).

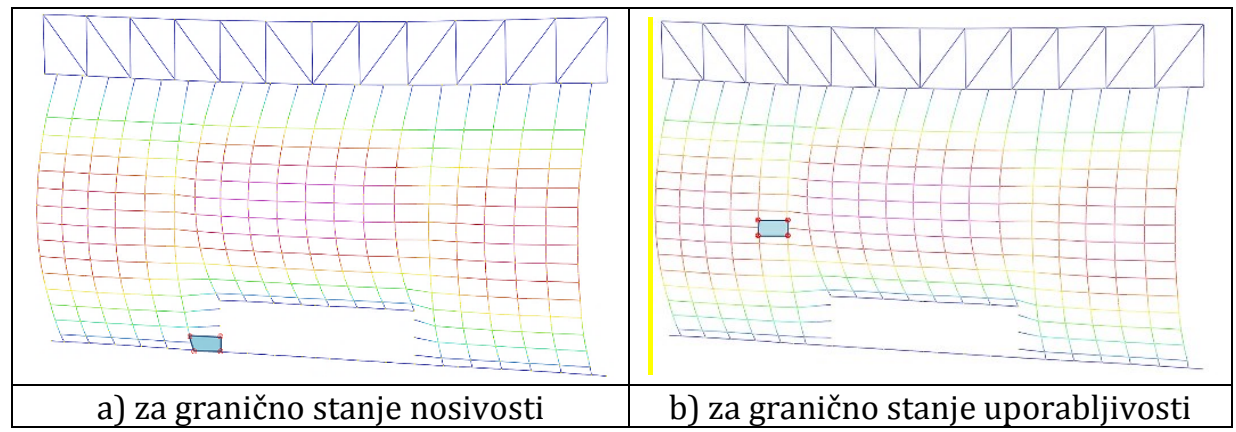

Slika 10. Pozicije stakala u provjerama graničnih stanja [1]

Provjeravana je tipična kompozicija (unutrašnje i vanjsko staklo 6.6.4 HS / PVB 1,52 mm, 16 mm zračne komore). Staklene ploče (1,0 x 1,7 m) su „kliještima“ učvršćene u uglovima, bez bušenja. Dopuštena naprezanja za kratkotrajno djelovanje (prema normi ASTM E1300-16: X6, X7), u polju i na rubu su $\sigma_{\mathrm{a}, \mathrm{s}}=46,6 \mathrm{MPa}$ i $\sigma_{\mathrm{a}, \mathrm{s}}=36,5 \mathrm{MPa}$, dok granični progib, mjeren po dijagonali duljine $L$ iznosi $L / 90$. Analize su provedena u SJ MEPLA 4.6.0 programu, za opterećenje vjetrom od $1,25 \mathrm{kPa}$ (Slike 11 i 12) i staklo pozicionirano između stupa ulaznog portala i kabela F4NW06 s najvećim relativnim pomacima točaka oslonaca prema Modelu A (Slika 10). Zbog relativno krutog pričvršćenja u trima točkama (oba donja i jedan gornji ugao), progib četvrtog ugla (prati kabel) izaziva vitoperenje stakla i vlačna naprezanja rubova.

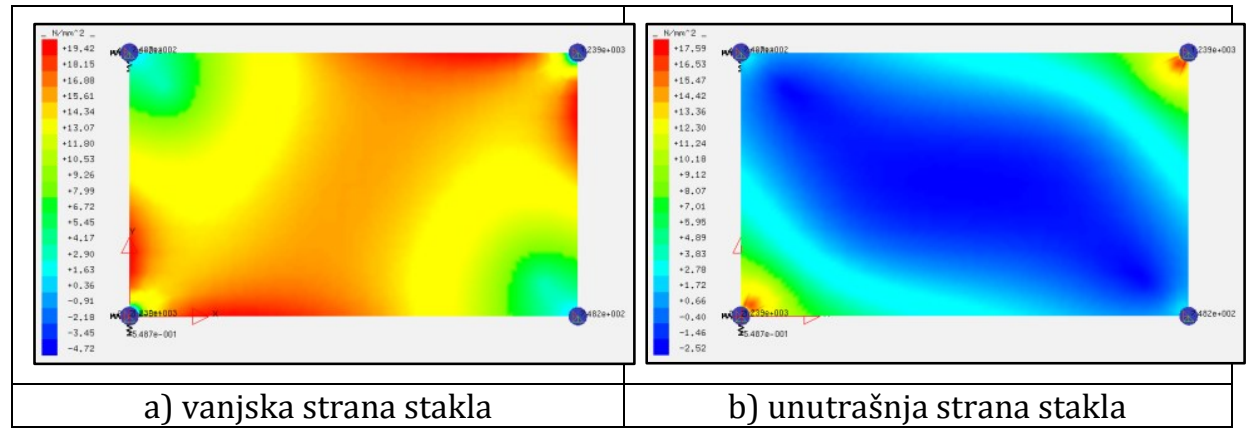

Slika 11. Pozicije Rezultati analize naprezanja stakla zbog vitoperenja [1] 


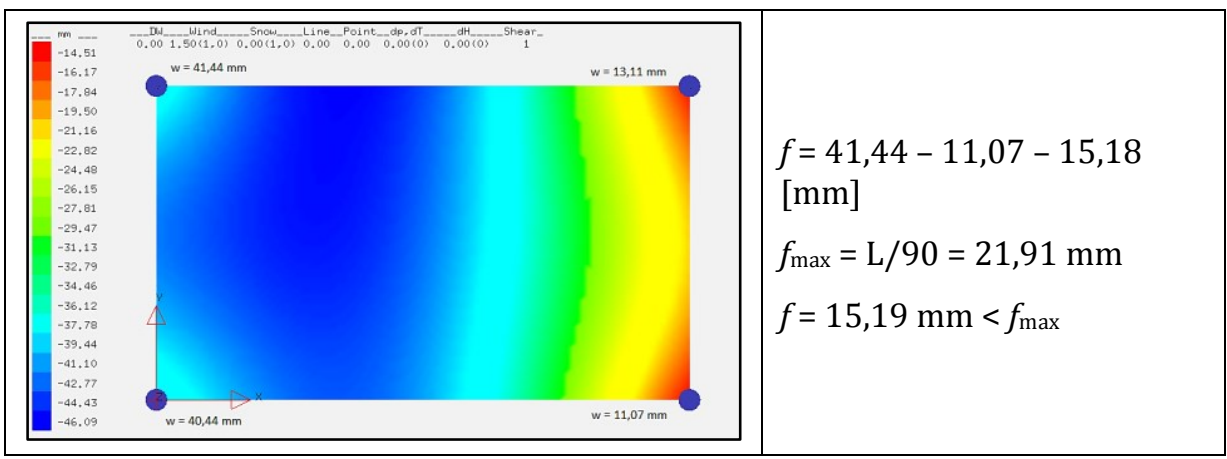

Slika 12. Rezultati analize progiba stakla zbog opterećenja vjetrom [1]

Za najveći pomak ugla 46,46 mm (Slika 11), vlačno naprezanje (na rubu vanjske strane stakla) iznosi 19,42 $\mathrm{MPa}<\sigma_{\mathrm{a}, \mathrm{s}}=36,5 \mathrm{MPa}$, zadovoljava provjera graničnog stanja nosivosti. Progib stakla je udaljenost od točke najvećeg progiba od opterećenja vjetrom (parabolična deformacijska linija) te dijagonalne spojnice uglova (Slika 12).

\subsection{Modeliranje i proračun konstrukcijskog silikona}

Konstrukcijski silikon je spoj između dvaju staklenih elemenata te stakla i kabela. Različiti progibi dvaju susjednih kabela (zbog prednapona) i deformiranje stakla zahtijevaju kompenzaciju pomaka u spoju s pojavom izduženja u silikonu i vlačnog naprezanja na spoju stakla i kabela.

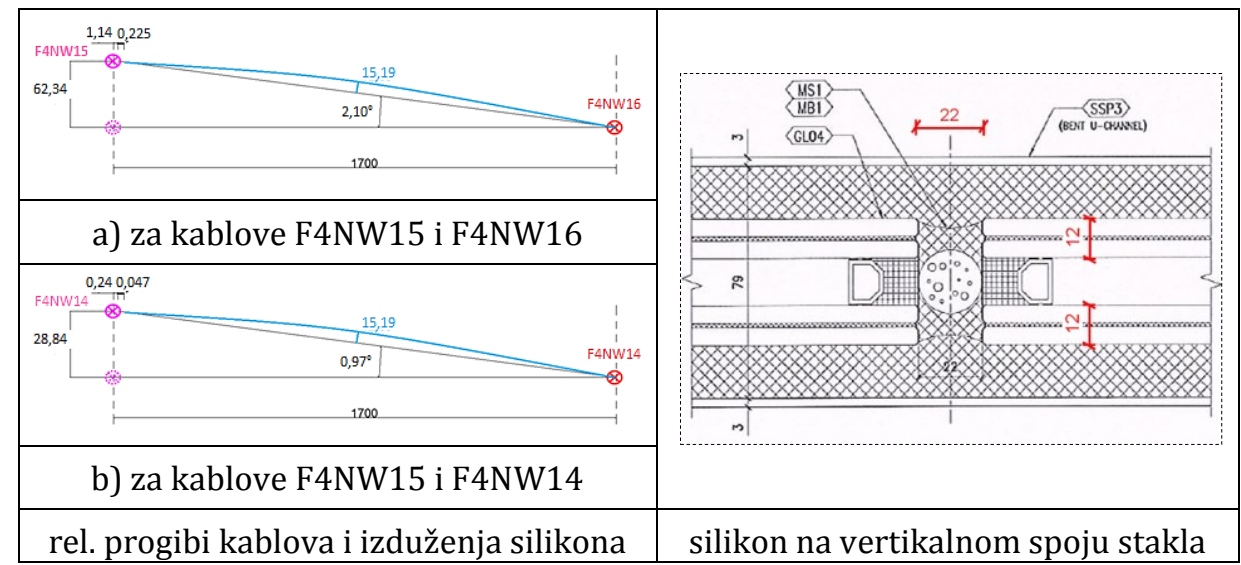

Slika 13. Izduženja silikona u vertikalnom spoju i presjek spoja stakla [1]

Provjerama treba dokazati vlačnu nosivost silikona te sposobnosti izduženja i kompenzacije pomaka (Slika 13) u vertikalnom spoju, zbog skraćenja tetive stakla i diferencijalnog progiba kabela. Za kapacitet izduženja od 50\% i dopušteno vlačno naprezanje $\sigma_{\text {dop }}=200 \mathrm{kPa}$ (prema 
specifikaciji proizvođača) provedene su provjere sposobnosti izduženja silikona širine $22 \mathrm{~mm}$ i vlačne otpornosti za napregnutu širinu od $24 \mathrm{~mm} \mathrm{u}$ vertikalnom spoju stakla (Slika 13). Provjere ukupnog izduženja s obje strane stakla provedene su za kabel F4NW15 s najvećim relativnim progibom u odnosu na susjedne kablove, proračunat iz Modela A (Slika 6). Za izduženja od diferencijalnog progiba kabela $(1,14 \mathrm{~mm}$ i $0,24 \mathrm{~mm})$ i progiba stakla $(0,225$ i $0,047 \mathrm{~mm})$, ukupni prirast izduženja u vertikalnom spoju s obje strane stakla iznosi 1,64 $\mathrm{mm}$ (suma prirasta od 1,365 $\mathrm{mm} \mathrm{i}$ $0,287 \mathrm{~mm}$ ), tj. $0,82 \mathrm{~mm}$, za 50\%-tni kapacitet izduženja te zadovoljava ograničenje izduženja od $11 \mathrm{~mm}$ (za širinu silikona $22 \mathrm{~mm}$ ). Vlačno naprezanje, proračunano za silu $F=446,84 \mathrm{~N}$ (Slika 6) i ploštinu silikona od $24000 \mathrm{~mm}^{2}$ (Slika 13) iznosi 18,62 $\mathrm{kPa}<\sigma_{\text {dop }}[1]$.

\subsection{Modeliranje i proračun oslonaca prednapetih kablova}

Spojevi kablova na glavnu nosivu konstrukciju imaju širok spektar rješenja ovisno o materijalu, veličini opterećenja te dostupnoj tehnologiji. Sastavni je dio proračuna ne samo staklene fasade, već i glavne nosive konstrukcije. Više podataka može se pronaći u [1] i [11].

\section{Zaključak}

Staklene fasade ovješene na prednapetim kablovima, razvijene kao težnja za ostvarivanja transparentnih i laganih fasada, afirmirale su se kao djelotvorni sustavi ostakljenja zahtjevne geometrije i površine. Ovaj rad s razlogom spaja metodologiju projektiranja i posebnosti ponašanja ovakvih sustava na proračunskom primjeru izvedene staklene fasade. Nedostatna pokrivenost ovog područja normama te evidentan interes istraživača za teme zanimljive i projektantima i istraživačima, od kojih smo neke naveli u uvodnom poglavlju, motivirale su nas da važnost interakcije fasade i glavne nosive konstrukcije istaknemo kao temu potencijalno zanimljivu za istraživanje, a rezultate koje smo dobili izdvojimo i kao smjernice proračuna.

Rezultati dobiveni dvama pristupima u modeliranju (označeni kao Model A i Model B), upućuju na veću pouzdanost integralnog modela te realniji opis stvarnog ponašanja konstrukcije uzimanjem u obzir interakcije sustava fasade i glavne nosive konstrukcije koji u konačnici jesu cjelovit sustav, a ne skup dijelova zasebnog ponašanja. Opravdanje za primjenu pojednostavnjenog modela mogu biti razlozi praktične naravi (izbjegavanje konflikta između izvođača staklene fasade i glavne nosive konstrukcije od kojih svaki odgovora samo za svoje područje rada).

Pokazano je i da se ne smiju zanemariti doprinosi horizontalnog ukrućenja stakala i utjecaji promjene temperature jer su važni za 
pouzdanost rezultata i ponašanje izvedene konstrukcije. Također, ne smije se zanemariti niti pojava vitoperenja stakla u području krutih oslonaca jer je pokazala kritičnijim utjecajem u usporedbi sa standardnim provjerama naprezanja i progiba.

Imajući u vidu rastući interes za primjenom ovih sustava fasada, rad koji čitate izraz je želje autora da ih približi javnosti i pobudi interes za edukacijom, istraživanjem i praćenjem suvremenih tendencija.

Zahvala. Ovaj je članak rezultat rada u znanstvenog projekta „Ocjena stanja i ojačanje građevinskih konstrukcija" koji se financira sredstvima Sveučilišta u Rijeci. Rezultat je i dugogodišnje uspješne suradnje Fakulteta $i$ tvrtke Ri-ISA d.o.o. u svim područjima naših djelatnosti.

\section{Literatura}

[1] Milovan, F. (2018) Staklena stijena ovješena na prednapetim kablovima. Diplomski rad. Rijeka: Građevinski Fakultet Sveučilišta u Rijeci.

[2] Mazeika, A., Kelly-Sneed, K., Getting Started with Cable-Net Walls, Modern Steel Construction, 2007, pp. 55-60

[3] Patterson, M., Structural Glass Facades and Enclosures, John Wiley \& Sons, New Jersey, 2011.

[4] Mustafasanie M. Yussof, Cable-Net Supported Glass Façade Systems, Doktorski rad, Faculty of Engineering and Physicals Sciences University of Surrey, 2015.

[5] Bedon, C. and Zhang, X. and Santos, F. and Honfi, D. and Kozlowski, M. and Arrigoni, M. and Figuli, L. et al., Performance of Structural Glass Facades under Extreme Loads - Design Methods, Existing Research, Current Issues and Trends. Construction and Building Materials, 163: pp. 921-937, 2018.

[6] R.-Q. Feng, Y. Wu and S.-Z. Shen, "Working Mechanism of Single-Layer CableNet Supported Glass Curtain Walls", Advances in Structural Engineering, 10(2), 183-195, 2007.

[7] R.-Q Feng, L.-L Zhang, Y. Wu and S.-Z. Shen, "Dynamic Performance of CableNet Façade", Journal of Constructional Steel Research, 65, 2217-2227, 2009.

[8] Grupa autora, Structural Use of Glass in Buildings (Second edition), The institution of Structural Engineers, London, 2014.

[9] Chhatrapati Shivaji International Airport - Terminal 2 / SOM, https://www.archdaily.com/477107/chhatrapati-shivaji-internationalairport-terminal-2-som, pristup 11.05.2018.

[10] Chhatrapati Shivaji Intern. Airport - Terminal 2 - structural engineering, http://www.som.com/projects/chhatrapati shivaji international airport te rminal 2 structural engineering, pristup 11.05.2018.

[11] Buljan, N.; Vorkapić A., Site Inspection Report - Assessment - Cable Glass Wall @L4 \& L2 at Mumbai International Airport (Mumbai, India), Rijeka, 2018. 